THURSDAY, OCTOBER 6, I870

\section{SCIENTIFIC ADMINISTRATION}

$\mathrm{N}^{\circ}$ reflecting Englishman can contemplate the great events of the present time without desiring to extract from them such warnings and instruction as may be serviceable to his country in case she should be drawn into war. Accordingly the press teems with discussions on every branch of the military art. We leave these to others. In what respects the constitution, the discipline, the training, and the arming of one army are superior to those of the other, it is scarcely the function of this journal to point out. Taking the broad fact that the Prussian army has, up to the present point, proved itself superior on the whole to that of France, and indeed to any army that has ever existed-a fact that no unprejudiced person will deny-let us ascertain, if we can, whether there may not be recognised some one broad cause to account for so broad a fact.

In this inquiry we have been almost forestalled by the Chancellor of the Exchequer at Elgin. Mr. Lowe recited the lessons which he considered we have to learn from the Prussians. He spoke of their "intelligence," their "organisation and docility," their "extraordinary knowledge, forecast, and diligence." $\mathrm{He}$ enumerated nearly all the qualities that command success. But there was one word which that profuse enumeration did not contain-a word which Mr. Lowé no doubt felt unable to utter, and that word is-Science. A Government which refuses aid to astronomers anxious to observe so rare a phenomenon as a total solar eclipse, cannot be éxpected to vaunt the prowess of science. Mr. Lowe's statement of the causes of Prussian success was therefore incomplete; it was a mere reckoning of the bricks of the building, without a word of its architecture and design.

The Prussians, whatever their other qualities, are emphatically a scientific people, and to that predominating characteristic first and foremost are their recent military triumphs due. We do not mean that because they are great chemists, astronomers, and physicists, therefore are they necessarily great soldiers; so narrow a proposition would hardly be tenable. What we mean is that the spirit of science possesses the entire nation, and shows itself, not only by the encouragement given throughout Germany to physical research, but above all by the scientific method conspictoous in all their arrangements. What does the word Science, used in its wider sense, imply? Simply the employment of means adequate to the attainment of a desired end. Whether that end be the constitution of a government, the organisation of an army or navy, the spread of learning, or the repression of crime, if the means adopted have attained the object, then science has been at work. The method is the same, to whatever purpose applied. The same method is necessary to raise, organise, and equip a battalion, as to perform a chemical experiment. It is this great truth that the Germans; above all other nations, if not alone amongst nations, have thoroughly realised and applied. In all the vast combinations and enterprises with which they have astounded the world, no one has been able to point to a single deficiency in any one essential element. Every post has been adequately filled and every want provided for; from the monarch, the statesman, and the strategist, to the lowest grade in the army--each department complete, each arm of the service, whether cavalry, infantry, or artillery, trained to its own special duties, and efficiently equipped for their performance. This is the method of science, literally the same method which teaches the chemist to prepare his retort, his furnace, and his re-agents, before commencing his experiment.

This, we maintain, is the great lesson, of a material kind, which the war should teach us. Where is our science? At the Admiralty and the War Office, partisan placemen preside over technical administrations. Is that science? Under pressure of the newspapers or of private influence, a ship of war is built by an amateur in spite of the demonstration of our professional adviser that she must be unsafe, and she goes accordingly to the bottom with 500 souls in the first gale of wind. Is that science? One-half of the forces on which we reckon for the defence of the nation is composed of patriotic volunteers, with whom training is optional, and to whom efficient officers and arms are denied. Is that science? The government of London, the greatest metropolis in the world, is parcelled out to scattered knots of ignorant, sordid tradesmen, on whom no ingenuity has ever been able to fix a shadow of responsibility. Is that science? Have we before us the crudest outline of the strategical and military operations with which it is proposed that an invasion of this country should be repelled? Coming political policfes always, in England, cast their shadows long before. Have we any indications of a coming military policy? Have we the means of calling together, in a short space of time, properly provided with the necessaries of a campaign, the forces requisite for carrying out a given military policy? Do we know, for instance, how our volunteers, who are reckoned on, man for man, as equivalent to regular troops, are to be employed?

We fear it is a terrible truth that absence of scientific method is as conspicuous with ts as its presence is with the Germans. As a nation, we have never realised the necessity for system and completeness in utilising our material resources. The use for the scientifically trained mind has, in our idea, been limited to chemicals and the like.

In courage, energy, intelligence, and wealth, natural and acquired, England need shrink from no comparisons with other nations, but she has yet to awake to the want of that something in her arrangements that shall enable her to turn her enormous advantages to the best account. Science, using the word in its sense of the method applied to things, not to the things themselves, is that something.

\section{OWENS COLLEGE, MANCHESTER}

CCASIONS may sometimes arise, and in fact have already arisen, when it becomes a necessity for a journal like ourselves, devoted exclusively to scientific matters, to direct some attention to what is going on around it in the general world. One of these lately occurred, and caused us to make the remarks we did recently on the apathy displayed by the Government 